\title{
Age-Related Alterations of Proteins in Albino Wistar Rat Retina
}

\author{
Andrea Kovács-Valasek ${ }^{\mathrm{a}, \mathrm{c}}$ Etelka Pöstyéni ${ }^{\mathrm{a}}$ Viktória Dénes $^{\mathrm{a}} \quad$ Adrienn Mester $^{\mathrm{a}}$ \\ György Sétáló Jr. ${ }^{b, c}$ Róbert Gábriel ${ }^{a, c}$ \\ aDepartment of Experimental Zoology and Neurobiology, Institute of Biology, Faculty of Sciences, University of \\ Pécs, Pécs, Hungary; b Department of Medical Biology, Medical School, University of Pécs, Pécs, Hungary; ' János \\ Szentágothai Research Centre, University of Pécs, Pécs, Hungary
}

\section{Keywords}

Immunohistochemistry · Western blot · Morphometric analysis · Retinal layers · Histology

\begin{abstract}
Imbalance of homeostasis causes permanent changes in the body with time. The central nervous system is especially prone to these changes since it possesses limited regenerative capacity. In the retina, neurons are damaged during the aging process, and this eventually leads to deterioration of vision. In our 2-year-long study, we examined genetically closely related rat individuals to disclose the hidden retinal causes of age-associated visual dysfunction. Morphometric analysis showed significant reduction of the retina thickness with aging, particularly that of the inner plexiform layer. To reveal changes between the age groups, we used immunohistochemistry against vesicular glutamate transporter 1 protein for photoreceptor and bipolar cell terminals, Brn3a for ganglion cells, calbindin $28 \mathrm{kDa}$ for horizontal cells, parvalbumin for All amacrines, protein kinase Ca for rod bipolar cells, tyrosine hydroxylase for dopaminergic cells, glial fibrillary acidic protein for glial cells, and peanut-agglutinin labeling for cones. The most significant decrease was observed in the density of photoreceptor and the ganglion cells in the aging process. By using immunocytochemistry and western
\end{abstract}

karger@karger.com www.karger.com/cto

Karger"

GOPEN ACCESS
(C) 2021 The Author(s)

Published by S. Karger AG, Basel

This is an Open Access article licensed under the Creative Common Attribution-NonCommercial-4.0 International License (CC BY-NC) (http://www.karger.com/Services/OpenAccessLicense), applicable to the online version of the article only. Usage and distribution for commercial purposes requires written permission. blot technique, we observed that calbindin and vesicular glutamate transporter 1 protein staining do not change much with aging; tyrosine hydroxylase, parvalbumin and calretinin showed the highest immunoreactivity during the midlife period. Most interestingly, the level of glial fibrillary acidic protein also changes similarly to the previously named markers. Our results provide further evidence that protein content is modified at least in some cell populations of the rat retina, and the number of retinal cells declined with aging. We conclude that senescence alone may cause structural and functional damage in the retinal tissue.

(c) 2021 The Author(s).

Published by S. Karger AG, Basel

\section{Introduction}

Aging is a natural component of life [Zahn and Kim, 2007; Tacutu et al., 2011]. Imbalance of the homeostasis originates from alteration of the environment causes permanent changes in the body with time. The central nervous system (CNS) is especially prone to losses of cells and proteins [Coleman and Flood, 1987; Majdi et al., 2009]. Since the CNS has a limited regenerative capacity, loss of function is inevitable over time [Lu et al., 2014; Tedeschi et al., 2017]. 
One of the best understood part of the vertebrate CNS is the retina, which is also sensitive for age-related changes [Samuel et al., 2011; Szabadfi et al., 2015]. Since the retina is a laminarly organized tissue it is especially suitable for monitoring changes in cell numbers [Gao and Hollyfield, 1992; Curcio and Drucker, 1993; Panda-Jonas et al., 1995; Aggarwal et al., 2007; Parikh et al., 2007]. At the same time there are remarkable changes in the thickness of the distinct retinal layers during the aging process, especially in the outer nuclear layer (ONL) [Kuhrt et al., 2012]. It has been also described that the amplitudes of electroretinographic a- and b-waves decline with normal aging [Birch and Anderson, 1992; Trick et al., 1992; Freund et al., 2011]. The age-related increase in retinal area and the stability in cell number suggests that the surface density of cells decrease with age [Samuel et al., 2011]. Although approximately in the first 3 months (97 days in albino and 84 days in pigmented rats), these aspects change dramatically; the following phase is characterized by moderate alterations only [Nadal-Nicolas et al., 2018a] . Age-related ocular growth does not perfectly follow retinal area extension. Consequently, the retinal coverage of the ocular surface decreases during postnatal development. In rats, this coverage factor decreases from 73 to $41 \%$ [Kuhrt et al., 2012].

Age-related cell loss, among other causes, has been assumed to lead to mitochondrial damage [El-Sayyad et al., 2014; Gkotsi et al., 2014; Kam and Jeffery, 2015; Sivapathasuntharam et al., 2017]. Deficits in the endogenous dopamine activity [Djamgoz et al., 1997] and/or a constant parainflammation [Xu et al., 2009; Arroba et al., 2018] have also been considered. The abovementioned authors have concluded that studying the effects of aging in experimental animals under a controlled environment and with similar genetic background can provide valuable information about the functional and anatomical impairment caused by senescence alone.

Selective effects of aging on particular components of neural circuitry, some of which may contribute to reduced visual function in old individuals, have also been studied. In rodents, aging causes morphological changes and/or loss of retinal ganglion cells (RGCs) and photoreceptors [Katz and Robison, 1986; Gao and Hollyfield, 1992; Semo et al., 2003; Cunea et al., 2014]. Other authors have not observed neuronal loss in the ganglion cell layer in aged animals while some studies have described that with age, the retina thins [Kim et al., 1996; Garcia-Ayuso et al., 2015; Nadal-Nicolas et al., 2018a].

In our previous reports, we have revealed the altered expression of cell type-specific marker proteins (tyrosine hydroxylase $[\mathrm{TH}]$, protein kinase $\mathrm{C} \alpha[\mathrm{PKC} \alpha]$, calbindin, calretinin, vesicular glutamate transporter 1 [vGLUT1], parvalbumin, glial fibrillary acidic protein [GFAP]) during the aging process of the retina in different aging models: degu [Szabadfi et al., 2015], PACAP KO mouse [Kovacs-Valasek et al., 2017]. In this study, we use the same marker set for better understanding of these age-related changes in genetically homogenous population of rats older than 5 months and to determine the stage of age when these alterations become significant.

In order to reveal the retinal causes of age-related vision loss, we performed a 2-year-long study using genetically closely related female rats, which were kept under standard and identical conditions to limit genetic variability and exclude differences in environmental conditions.

\section{Material and Methods}

Animals

Wistar albino female rats originated from 2 sister litters were housed under identical conditions: in a temperature- $\left(23^{\circ} \mathrm{C}\right)$ and light- (12/12h light/dark cycles) controlled room, with water and food ad libitum. Four separate cohorts were examined: 5-, 12-, 18-, and 24-month-old rats. Animals were sacrificed by an overdose of Forane anesthetic, and the eyes were immediately dissected in icecold phosphate buffered saline (PBS; pH 7.4).

\section{Histology}

Retinas were processed for histological analysis as previously described [Atlasz et al., 2010]. Briefly, the eye was enucleated, then immediately cut open. The eyecups of each animal were immersed in $1 \%$ glutaraldehyde-PFA overnight then dehydrated through ascending ethanol series. Finally, the tissue was embedded in Durcupan ACM resin (Merck, Budapest, Hungary). Resin sections were cut at $2 \mu \mathrm{m}$ (Leica, Germany) within 1-2 mm distance from the optic nerve head and were stained with $1 \%$ toluidine blue (Sigma, Budapest, Hungary). The cross-section of the retina from outer limiting membrane to the inner limiting membrane and the width of individual retinal layers were measured using a Nikon Eclipse $80 \mathrm{i}$ microscope ( $\times 20$ magnification objective) and the SPOT Basic program. At each age, we examined 15 microscopy frames (each frame measuring $500 \mu \mathrm{m}$ ) per eye, taken from a minimum of 4 animals. Values represent mean \pm SEM.

\section{Immunohistochemistry and Peanut-Agglutinin Labeling}

The other eyecups of each animal were fixed in 4\% PFA for $2 \mathrm{~h}$ at room temperature, cryoprotected in 15 and $30 \%$ sucrose solutions at $4^{\circ} \mathrm{C}$. Retinal cryo-sections were washed with PBS 6 times for $5 \mathrm{~min}$ and blocked with normal goat serum for $1 \mathrm{~h}$ at room temperature. Then sections were incubated with either fluorescein isothiocyanate (FITC)-conjugated peanut-agglutinin (Vector Laboratories, Hungary; 1:1000) or primary antibodies (Table 1) overnight at room temperature and the next day with the corresponding secondary fluorescent antibodies for $2 \mathrm{~h}$ (Table 2). All sections 
Table 1. Primary antibodies used in immunohistochemical and western blotting experiments

\begin{tabular}{llllll}
\hline Catalog No. & Primary antibodies & Raised in & $\begin{array}{l}\text { Dilution } \\
\text { immunohistochemical }\end{array}$ & $\begin{array}{l}\text { Dilution western } \\
\text { blotting }\end{array}$ & Company \\
\hline SC8429 & anti-Brn3a & Mouse & $1: 50$ & - & $\begin{array}{l}\text { Santa Cruz, USA } \\
\text { VectorLab, UK }\end{array}$ \\
FL1071 & PNA (FITC conjugated) & & $1: 1,000$ & - & Sigma, Hungary \\
C9848 & anti-Calbindin & Mouse & $1: 1,000$ & $1: 1,000$ & Santa Cruz, USA \\
SC17804 & anti-PKCa & Mouse & $1: 200$ & $1: 200$ & Millipore, Hungary \\
MAB318 & anti-TH & Mouse & $1: 1,000$ & $1: 500$ & Sigma, Hungary \\
P3088 & anti-Parvalbumin & Mouse & $1: 1,000$ & $1: 1,000$ & Swant, USA \\
PV235 & anti-Calretinin & Mouse & $1: 1,000$ & $1: 1,000$ & Abcam, UK \\
ab77822 & anti-vGLUT1 & Rabbit & $1: 500$ & $1: 1,000$ & Sigma, Hungary \\
G9269 & anti-GFAP & Rabbit & $1: 500$ & $1: 10,000$ & Sigma, Hungary \\
G9545 & Anti-GAPDH & Rabbit & - & & \\
\hline
\end{tabular}

Table 2. Secondary antibodies used in immunohistochemical and western blotting experiments

\begin{tabular}{|c|c|c|c|c|}
\hline Catalog number & Secondary antibodies for immunohistochemical & Raised in & Dilution & Company \\
\hline A11001 & anti-mouse IgG conjugated with Alexa Fluor 488 & Goat & $1: 1,000$ & Life Technologies, USA \\
\hline A11011 & anti-rabbit IgG conjugated with Alexa Fluor 568 & Goat & $1: 1,000$ & Life Technologies, USA \\
\hline Catalog number & Secondary antibodies for western blotting & Raised in & Dilution & Company \\
\hline $65-6120$ & anti-rabbit IgG conjugated with HRP & Goat & $1: 10,000$ & Life Technologies, USA \\
\hline
\end{tabular}

from different points of time were processed at once, using the same incubating solutions. Photographs were taken with an Olympus Fluorview FV-1000 Laser Confocal Scanning Microscope (Olympus, Japan), using the same settings (laser intensity of blue laser was 580 units and the green laser was 750 units; pinhole was $130 \mu \mathrm{m}$ for green channel and 135 for red channel; optical section thickness was $1 \mu \mathrm{m}$ ) for one marker. The number of Brn3a-positive RGCs and cone terminals $/ 100 \mu \mathrm{m}$ retina length were also counted. Results are presented as mean \pm SEM. Statistical comparisons were made using Student's $t$ test and one-way ANOVA $(p<0.05)$.

\section{Western Blot Analyses}

Dissected retinas ( $n=4$ per age group) were homogenized in RIPA buffer (10 mM phosphate buffer, $15 \mathrm{mM} \mathrm{NaCl}, 0.1 \%$ SDS, $1 \%$ sodium-deoxycholate, 1\% NP40, 2 mM EDTA, $2 \mu \mathrm{g} / \mathrm{mL}$ aprotinin, $0.5 \mu \mathrm{g} / \mathrm{mL}$ leupeptin, $2 \mathrm{~mm}$ sodium-vanadate, $20 \mathrm{~mm}$ sodium-fluoride, $0.5 \mathrm{mM}$ DTT, and $1 \mathrm{mM}$ PMSF). To remove insoluble material, homogenates were centrifuged at $13,000 \mathrm{rpm}$ for $30 \mathrm{~min}$ at $4^{\circ} \mathrm{C}$ and the clear supernatants were stored at $-80^{\circ} \mathrm{C}$ until use. Protein concentrations were determined with the BCA Protein Assay Kit (Thermo-Fisher, Budapest, Hungary) using BSA as a standard. Samples $(20 \mu \mathrm{g}$ protein/well) were electrophoresed on $4-12 \% \mathrm{Nu}-$ PAGE SDS-polyacrylamide gels (Thermo-Fisher, Budapest, Hungary), then transferred onto PVDF membranes (Bio-Rad, Budapest, Hungary). Following transfer, the PVDF membranes were blocked with blocking solution containing $20 \mathrm{mM}$ Tris- $\mathrm{HCl}, 150$
mM NaCl, 0.1\% Tween-20, 5\% non-fat dry milk, and 1\% BSA for $60 \mathrm{~min}$ at room temperature. Membranes were sequentially probed overnight at $4^{\circ} \mathrm{C}$ with primary antibodies (Table 1), and the following day they were incubated with the appropriate secondary antibody (Table 2) for $2 \mathrm{~h}$. Finally, blots were developed by incubating in enhanced chemiluminescence reagent (Advansta, San Jose, CA, USA) with Chemi Doc System (Bio-Rad, Budapest, Hungary). As a normalization control, GAPDH was used. Optical densities (OD) of the bands were normalized using the value found for the 12 -month-old animals. Data are presented normalized OD \pm SEM $(n=4$; one-way ANOVA, Tukey-B Post hoc analysis; $p<0.05)$.

\section{Results}

We carried out histological, immunohistochemical, and western blot analyses on rat retinas of different ages. Immunostaining for standard neurochemical markers (Brn3a for ganglion cells, peanut-agglutinin for cone photoreceptor cells, calbindin $28 \mathrm{kDa}$ for horizontal cells, PKCa for rod bipolar cells, TH for dopaminergic and parvalbumin for AII amacrines, as well as calretinin for certain populations of amacrine and ganglion cells) revealed 


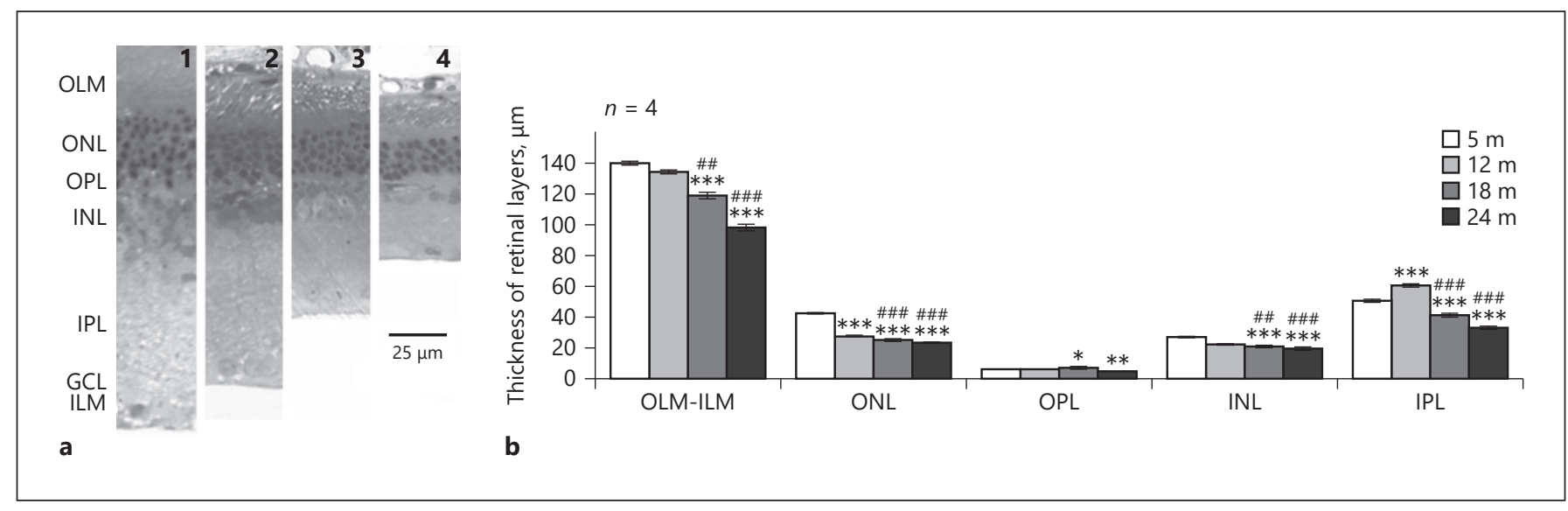

Fig. 1. Retinal layers in different age groups. a Representative sections of rat retinas of 5-month- (1), 12-month- (2), 18-month- (3), 24-month- (4) old animals stained with toluidine blue for light microscopy. Scale bar, $25 \mu \mathrm{m}$. b Thickness of retinal layers. OLM, outer limiting membrane; ONL, outer nuclear layer; OPL, outer plexiform layer; INL, inner nuclear layer; IPL, inner plexiform layer; GCL, ganglion cell layer; ILM, inner limiting membrane. Data are presented as mean \pm SEM. ${ }^{* * *} p<0.001$, ${ }^{* *} p<0.01$, and ${ }^{*} p<$ 0.05 compared to mature rats. \#\#\# $p<0.001$ and \#\# $p<0.01$ compared to 12-month-old animals.
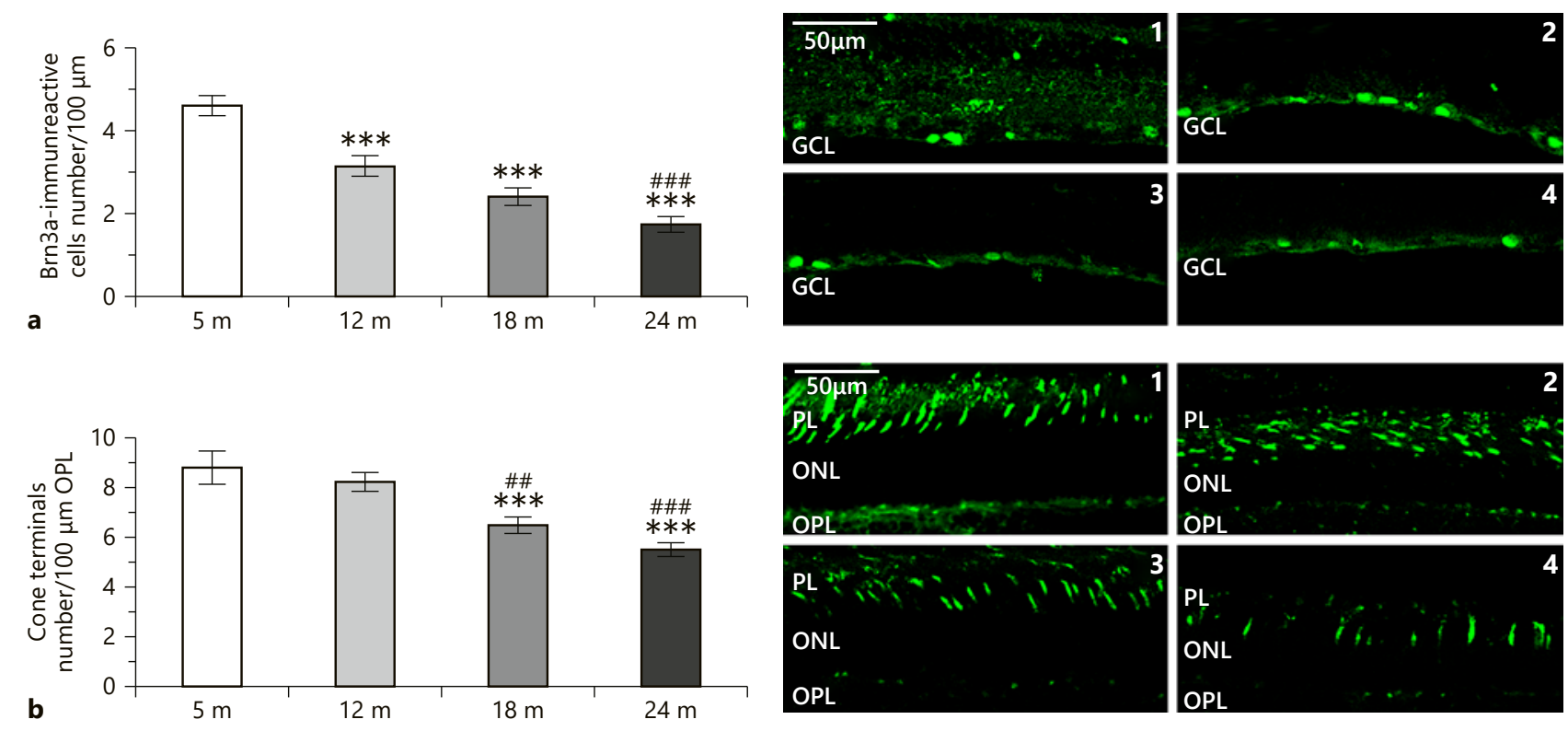

Fig. 2. Representative images of rat retinas 5 months (top 1, bottom 1), 12 months (top 2, bottom 2), 18 months (top 3, bottom 3), and 24 months (top 4, bottom 4) stained with Brn3a for ganglion cell density (a) and PNA for cone terminal density (b). GCL, ganglion

cell layer; PL, photoreceptor layer; ONL, outer nuclear layer; OPL, outer plexiform layer. Scale bar, $50 \mu \mathrm{m}$. Data are presented as mean \pm SEM. ${ }^{* * *} p<0.001$ compared to mature rats. \#\#\# $p<0.001$ and \#\# $p<0.01$ compared to 12 -month-old animals.

changes in neuronal structures between the age groups. Furthermore, we examined a synaptic protein, vGLUT1 and a metabolic stress-responsive glial marker protein, GFAP.

Morphometric analysis revealed significant decrease in the thickness of each retinal layer with age, especially in the inner plexiform layer (IPL) (shown in Fig. 1a, b). The most prominent reduction in cell number occurred in the ONL 

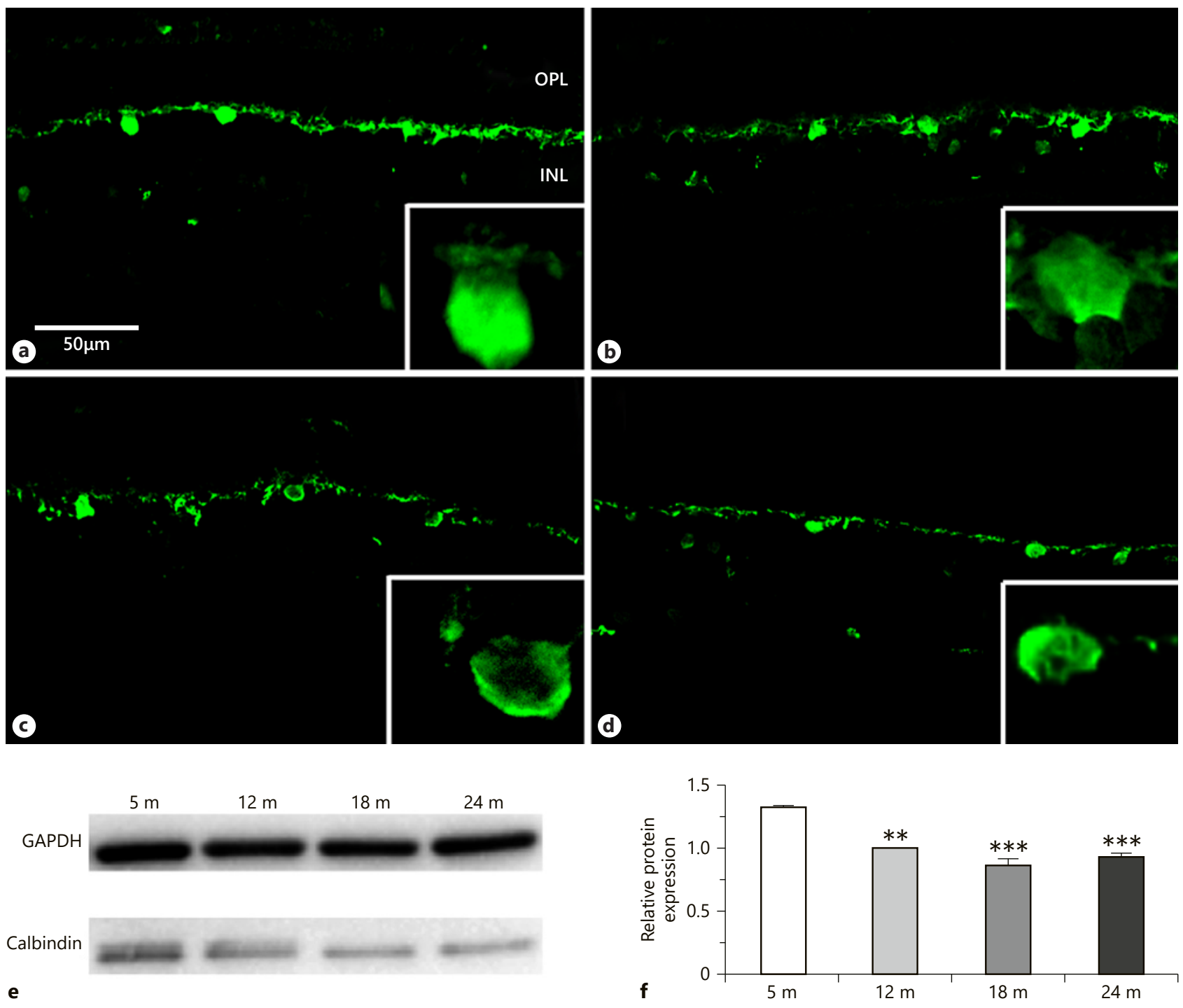

Fig. 3. Calbindin immunoreactivity in horizontal cells. Immunohistochemical labeling for 5 months (a), 12 months (b), 18 months (c), and 24 months (d), and western blot analysis (e, f). OPL, out- er plexiform layer; INL, inner nuclear layer. Scale bar, $50 \mu \mathrm{m}$. Data are presented as mean \pm SEM. ${ }^{* * *} p<0.001$ and ${ }^{* *} p<0.01 \mathrm{com}-$ pared to 5-month-old mature animals. containing the photoreceptors which also appeared in lower densities at later ages (Fig. 2b). The density of ganglion cells also declined during the aging process (Fig. 2a).

Calcium-binding proteins are excellent markers of different subpopulation of neurons in the retina, and their expression show age-related changes [Papazafiri et al., 1995]. In our work, we examined 3 different calciumbinding proteins (calbindin, parvalbumin, calretinin) in the rat retina during the aging process. The sections at subsequent ages showed that the horizontal cell bodies and the outer plexiform layer (OPL) remained strongly stained by anti-calbindin antibodies. This staining decreased somewhat in intensity (Fig. 3a-d) although it showed less prominent difference during the aging progress than the other calcium-binding proteins (see below). Western blots confirmed this pattern (Fig. 3e, f). 

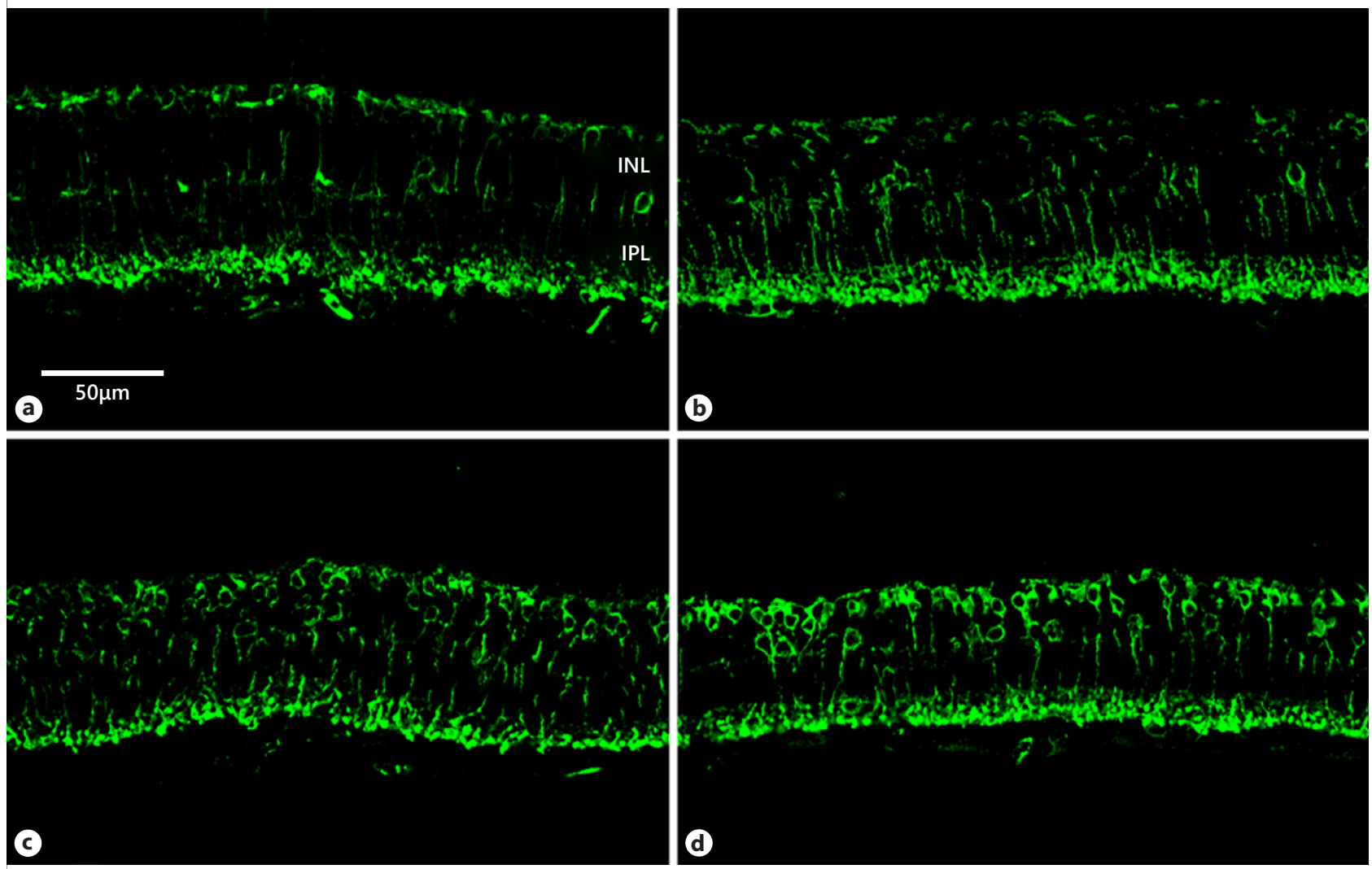

$5 \mathrm{~m}$

$12 \mathrm{~m}$

$18 \mathrm{~m}$

GAPDH

PKCa

Fig. 4. PKCa immunoreactivity in rod bipolar cells. Immunohistochemical labeling for 5 months (a), 12 months (b), 18 months (c), and 24 months (d), and western blot analysis (e, f). INL, inner nuclear layer; IPL, inner plexiform layer. Scale bar, $50 \mu \mathrm{m}$. Data are presented as mean \pm SEM. ${ }^{* * *} p<0.001$ compared to mature rats. \#\#\# $p<0.001$ compared to 12 -month-old animals.
Rod bipolar cells can be selectively stained with antibody against $\mathrm{PKC} \alpha$ and show decreased density in human and degu retina during aging [Aggarwal et al., 2007; Szabadfi et al., 2015]. We used PKCa antibodies for the detection of alterations of rod bipolar cells staining intensity at different age stages. Dendrites in the OPL, the cell bodies in the inner nuclear layer (INL) and axons terminating at the border of the IPL and ganglion cell layer

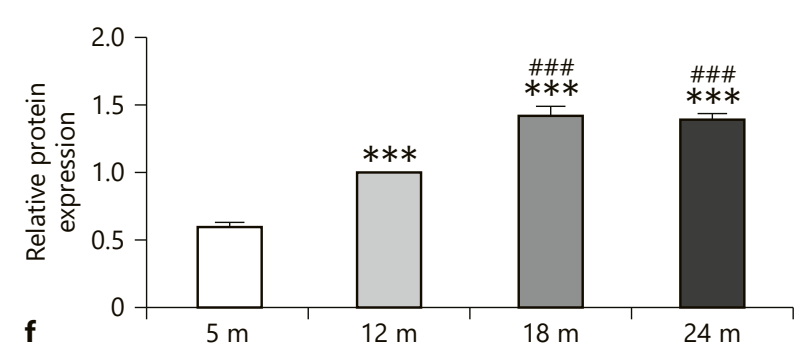

were stained for PKCa (Fig. 4a-d). Labeling pattern does not show remarkable changes, but the intensity was constantly increasing (both the cell bodies and the terminals in the IPL) during aging, except the last time period when it remained constant. Western blotting confirmed these trends (Fig. 4e, f).

A decreased $\mathrm{TH}$ immunoreactivity has been revealed in aging human and PACAP KO mouse retina [Roufail 


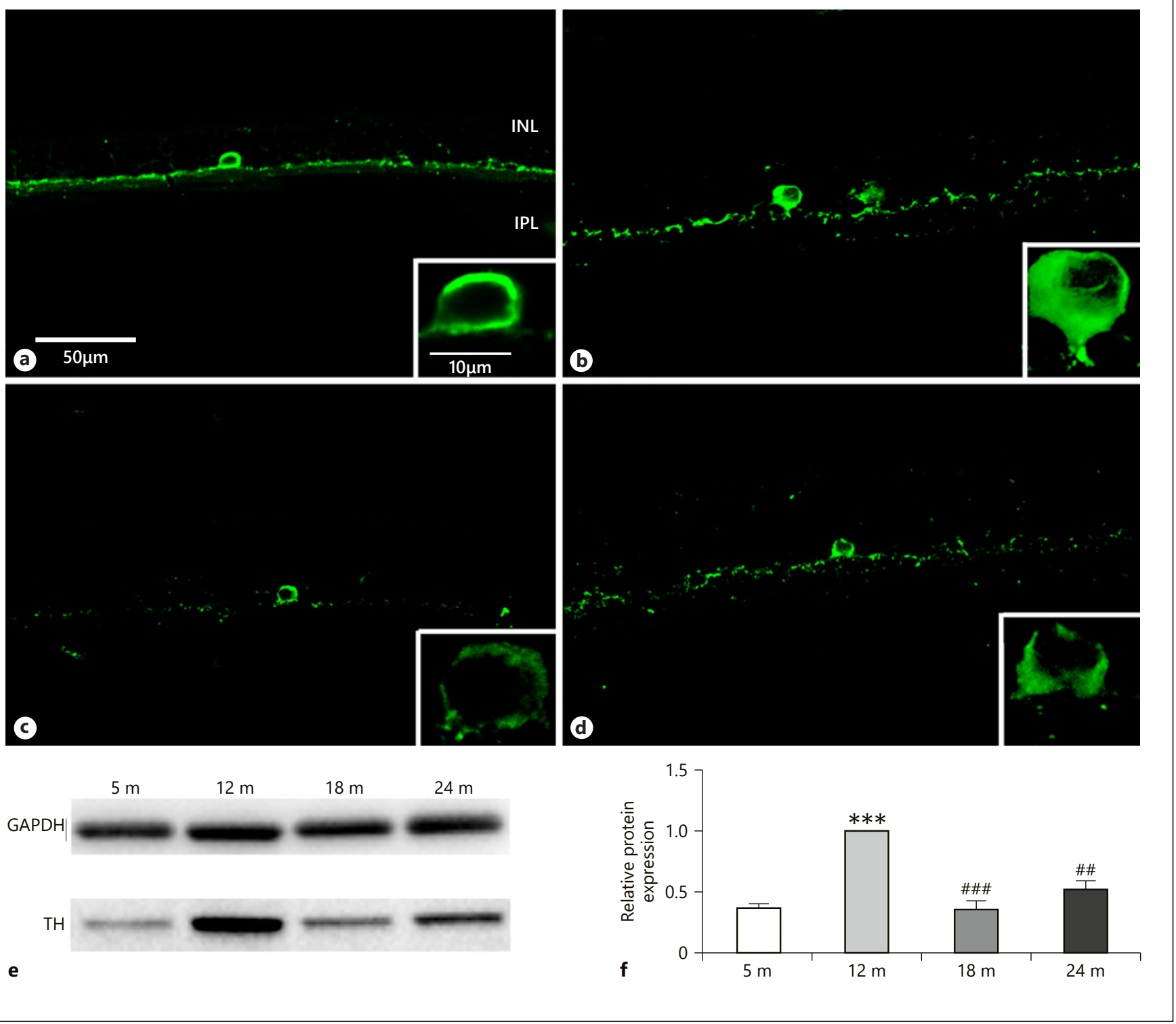

Fig. 5. TH immunoreactivity in dopaminergic amacrine cells. Immunohistochemical labeling for 5 months (a), 12 months (b), 18 months (c), and 24 months (d), and western blot analysis (e, f). INL, inner nuclear layer; IPL, inner plexiform layer. Scale bar, 50

$\mu \mathrm{m}$. Data are presented as mean \pm SEM. ${ }^{* * *} p<0.001$ compared to mature rats. \#\#\# $p<0.001$ and \#\# $p<0.01$ compared to 12 -monthold animals.

and Rees, 1997; Kovacs-Valasek et al., 2017]. Therefore, antibodies against TH were also used to study the level of this protein during the aging process in our present study. We revealed that $\mathrm{TH}$ expression reached a maximum at 12 months and has shown decreased levels afterward (Fig. 5a-d). Western blotting confirmed these results showing the highest protein level at 12 months (Fig. 5e, f).

Parvalbumin has long been considered as one of the most reliable markers of retinal cells [Endo et al., 1986; Sanna et al., 1990]. The cell bodies of AII amacrine cells in the IPL are intensively labeled by antibodies against parvalbumin in all examined age groups (Fig. 6a-d). Weakly immunoreactive structures, probably bipolar cells, were found in the INL, over and above immunore- 


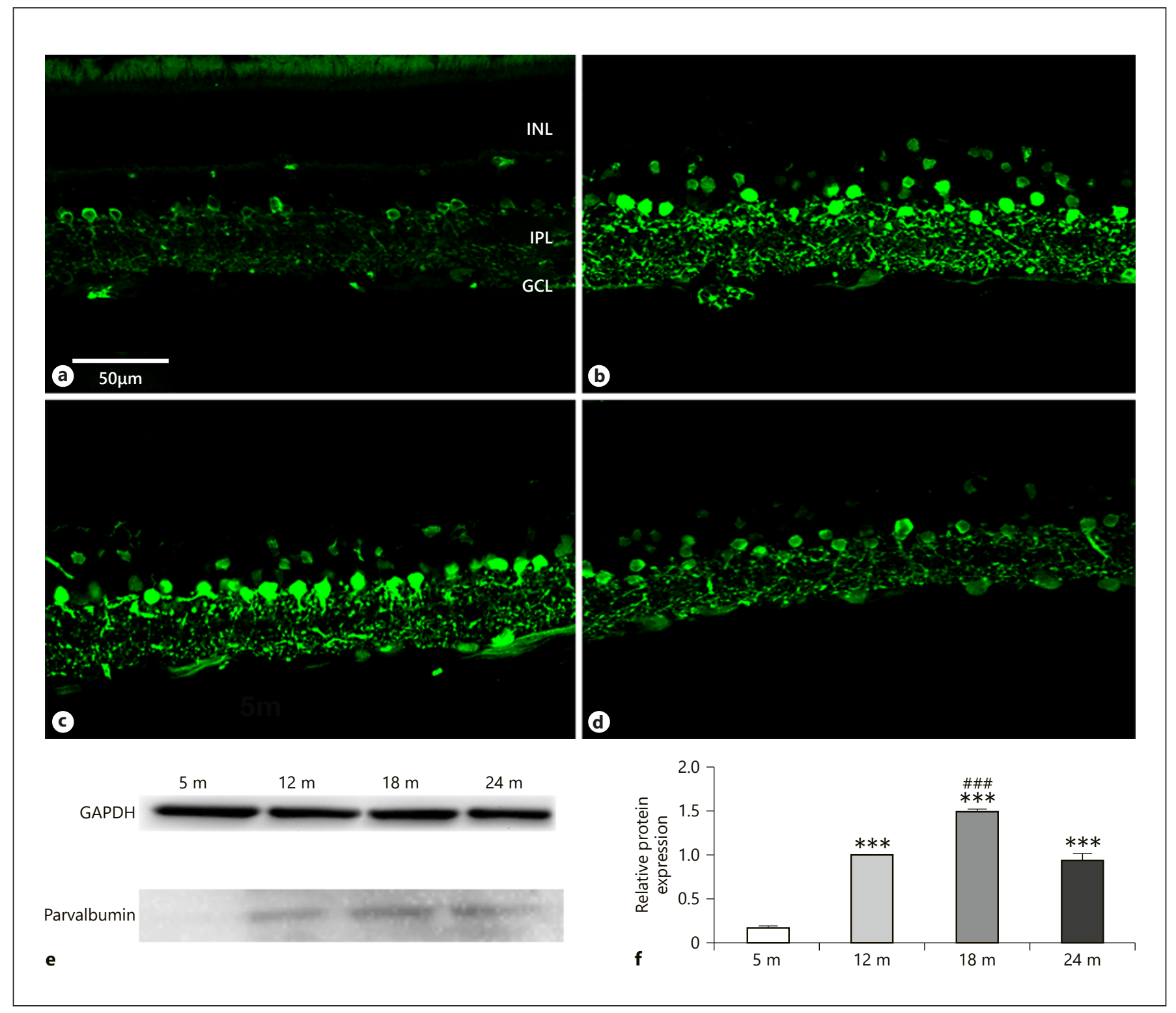

Fig. 6. Parvalbumin immunoreactivity in AII amacrine cells. Immunohistochemical labeling for 5 months (a), 12 months (b), 18 months (c), and 24 months (d), and western blot analysis (e, f). INL, inner nuclear layer; IPL, inner plexiform layer; GCL, ganglion

cell layer. Scale bar, $50 \mu \mathrm{m}$. Data are presented as mean \pm SEM. *** $p<0.001$ compared to mature rats. \#\#\# $p<0.001$ compared to 12 -month-old animals.

active amacrine cells. Those were detected in retinas of 12 and 18 months (Fig. 6b, c). Some ganglion cells showed moderate immunoreactivity at the same points of time (Fig. 6a-d). The intensity of the labeling was first increasing during aging (Fig. $6 \mathrm{a}-\mathrm{c}$ ) and declined after 18 months (compare Fig. $6 \mathrm{c}$ to Fig. 6d). This trend was confirmed by protein level measurements (Fig. 6e, f).

Calretinin has been localized to different neuron populations in the vertebrate retina [Pasteels et al., 1990]. Lately, it has been shown that the direction selective cholinergic cells contain calretinin in the rat retina [Gabriel and Witkovsky, 1998]. Besides the cholinergic cells, calretinin labeling was detected in some other amacrine cells and ganglion cell bodies and formed 3 distinct bands of the IPL (Fig. $7 \mathrm{a}-\mathrm{d}$ ). In the first year, immunoreactive 

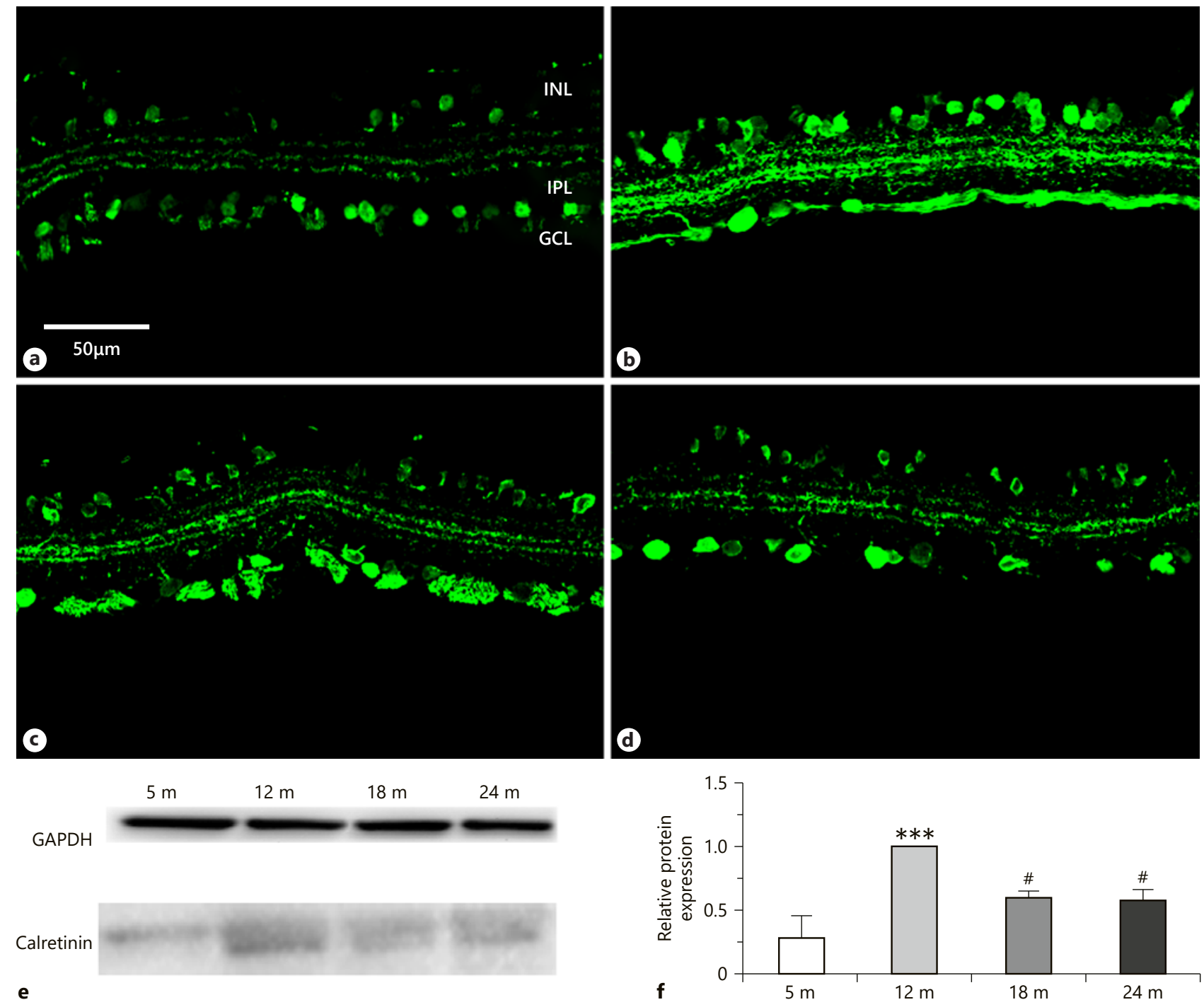

Fig. 7. Calretinin immunoreactivity in amacrine and ganglion cells. Immunohistochemical labeling for 5 months (a), 12 months (b), 18 months (c), and 24 months (d), and western blot analysis $(\mathbf{e}, \mathbf{f})$. INL, inner nuclear layer; IPL, inner plexiform layer; GCL,

ganglion cell layer. Scale bar, $50 \mu \mathrm{m}$. Data are presented as mean \pm SEM. ${ }^{* * *} p<0.001$ compared to mature rats. $\# p<0.05$ compared to 12 -month-old animals.

bands in the IPL were weaker (Fig. 7a, b) than at later ages (Fig. 7c, d). Subpopulations of amacrine and ganglion cells were also densely labeled. Amacrine cells and the IPL were very intense at 12 months (Fig. 7b). The highest immunoreactivity was seen already at 12 months of age both by immunostaining and western blot analysis (Fig. 7e, f). The labeling pattern did not change much during the examined time period.

Glutamate is a dominant excitatory neurotransmitter in the retina, and vesicular glutamate transporters take part in filling synaptic vesicles with this substance [FykKolodziej et al., 2004]. Among these transporters vGLUT1 is a major player, and its level changes significantly during the aging process [Szabadfi et al., 2015; Kovacs-Valasek et al., 2017]. In our experiments, the vGLUT1 protein expression did not show remarkable changes in the 

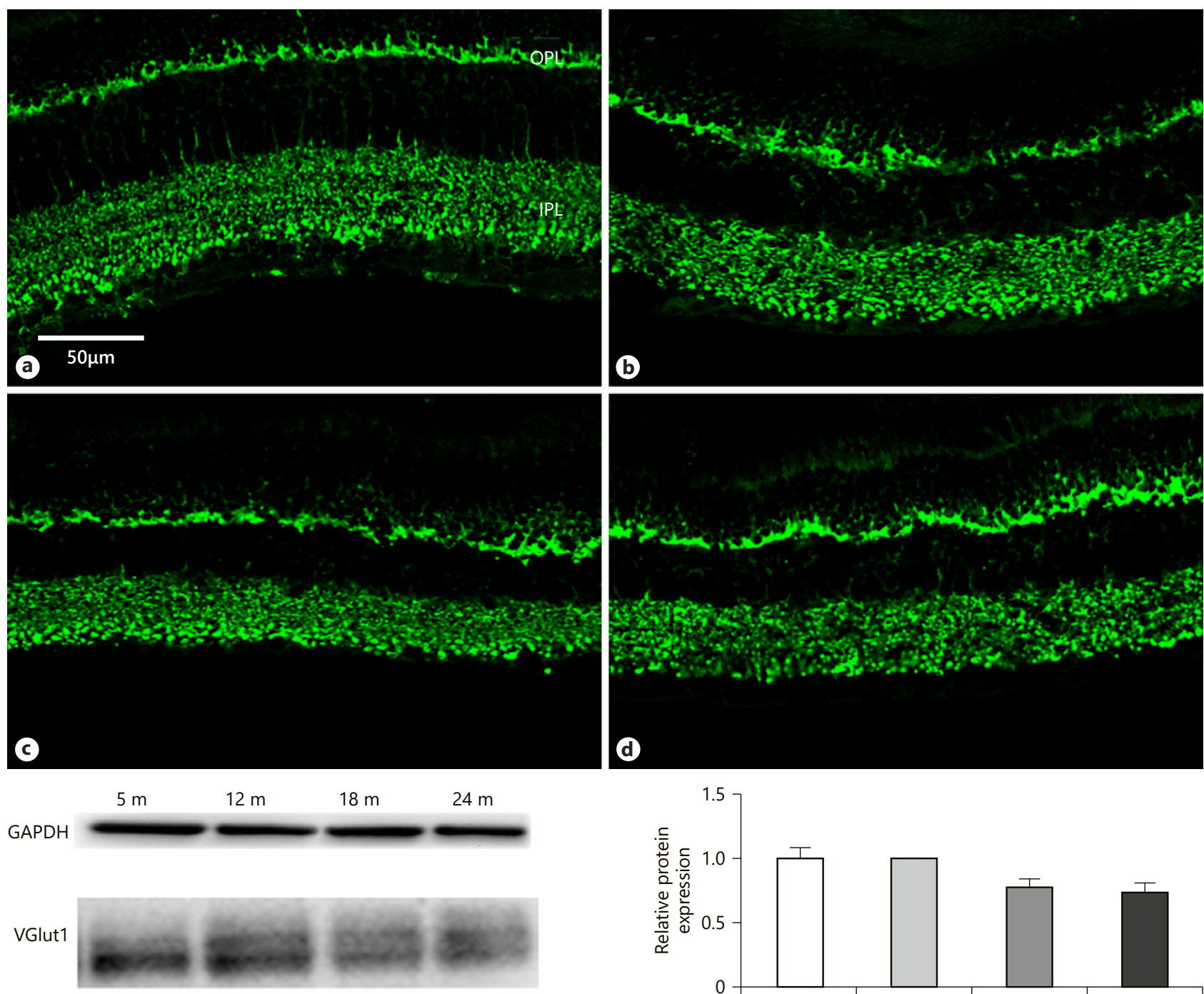

e

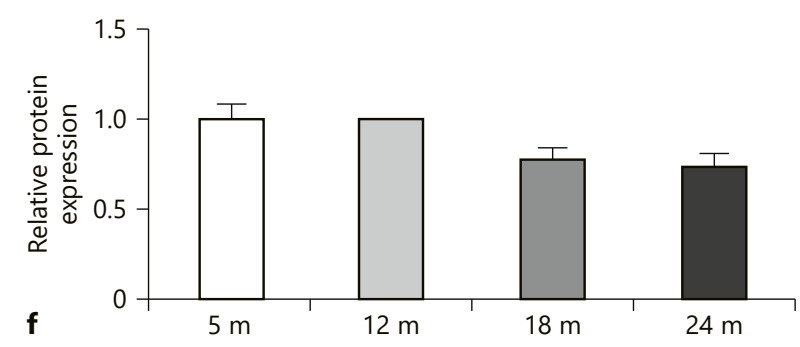

Fig. 8. vGLUT1 immunoreactivity in photoreceptor and bipolar cell terminals. Immunohistochemical labeling for 5 months (a), 12 months (b), 18 months (c), and 24 months (d), and western blot analysis (e, f). OPL, outer plexiform layer; IPL, inner plexiform layer. Scale bar, $50 \mu \mathrm{m}$.

retinal tissue neither by immunocytochemistry (Fig. $8 \mathrm{a}-$ d) nor by western blotting (Fig. 8e, f). Among all, this marker proved to be the most constant during the aging process.

The GFAP is a stress indicator in the retina and during the senescence shows altered expression changes [Lundkvist et al., 2004]. In this study, GFAP staining has shown a remarkable change during the 24 months (Fig. 9a-d). While low at 5 months (Fig. 9a), strong elevation was seen at 12 and less intense increase at 18 and 24 months (Fig. 9a-d), and it declined again at 24 months (Fig. 9d). Interestingly, at older ages (18 and 24 months), both the immunocytochemical staining and the protein level of GFAP measured by western blotting occurred less intense and the blots showed fewer isoforms at 24 months than at earlier ages (Fig. 9e, f). 

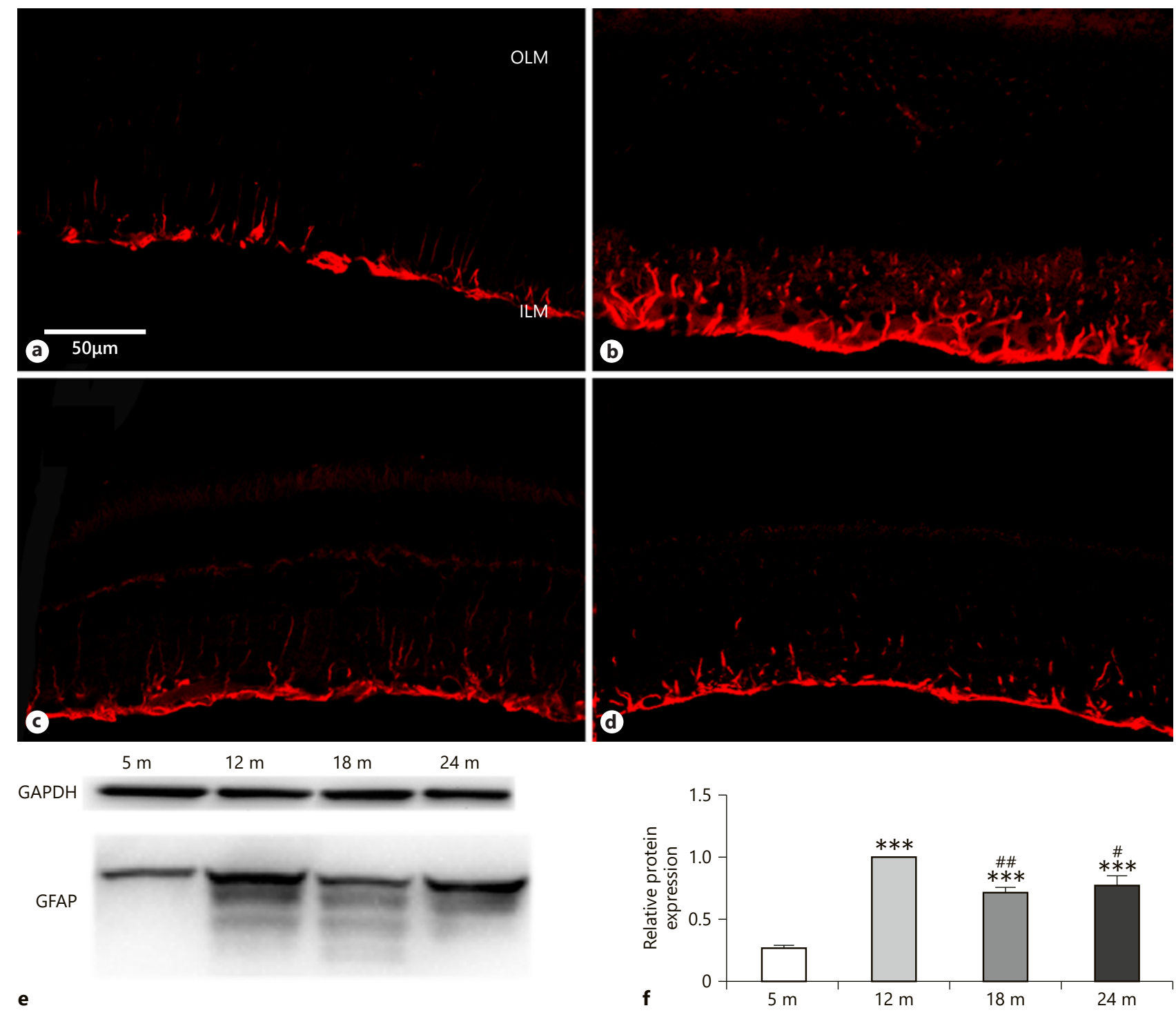

Fig. 9. GFAP immunoreactivity in glial cells. Immunohistochemical labeling for 5 months (a), 12 months (b), 18 months (c), and 24 months (d), and western blot analysis (e, f). OLM, outer limiting membrane; ILM, inner limiting membrane. Scale bar, $50 \mu \mathrm{m}$. Data are presented as mean \pm SEM. ${ }^{* * *} p<0.001$ compared to mature rats. $\# \# p<0.01$ and $\# p<0.05$ compared to 12 -month-old animals.

\section{Discussion}

Aging phenotype varies between tissues and includes common hallmarks such as genomic and epigenetic instability, mitochondrial dysfunction, telomere attrition, and the accumulation of senescent cells [Deschenes and Chabot, 2017]. Any combination of the above processes will have basic influence on the speed of tissue deterioration and cell death. Since the retina is the metabolically most active organ in the mammalian body [Graymore, 1970; Kumagai, 1999; Nivison-Smith et al., 2015]and there is very limited regenerative capacity in the CNS, it is particularly prone to damage due to aging, which has been demonstrated by several authors [Gao and Holly- 
field, 1992; Curcio and Drucker, 1993; Panda-Jonas et al., 1995; Kim et al., 1996; Liets et al., 2006; Aggarwal et al., 2007; Parikh et al., 2007; Freund et al., 2011; Samuel et al., 2011; Cunea et al., 2014] in several species including rats [Cano et al., 1986; Papazafiri et al., 1995; Mansour et al., 2008; Nadal-Nicolas et al., 2018a; Mohamed et al., 2019]. The majority of these papers deals with male subjects. In a mixed gender study [Chaychi et al., 2015], results show that male and female retinas change very similarly during aging. We chose female rat individuals to reveal the aging processes due to the longer lifespan of the female subjects; therefore, the chances of being able to keep enough individuals alive for more than 2 years were higher and the number of experimental animals could be optimized better.

In our study, retinal aging of genetically closely related female rat individuals (sister litters) kept under entirely identical conditions for a long period of time (up to 2 years) were studied utilizing standard cellular markers.

\section{Retinal Cell Type-Specific Observations}

In this study, the investigated cell markers were listed in 3 different groups based on their expression pattern during the aging process. Some of these showed a steady decrease (peanut-agglutinin-labelled cones and Brn3a positive ganglion cells), others showed a midlife peak in their expression (TH, parvalbumin, calretinin, GFAP), while other proteins (calbindin, vGLUT1) do not change much during normal aging. Previous studies described the decrease of neuronal cell number in the aged retina [Weisse, 1995; Aggarwal et al., 2007; Samuel et al., 2011], and we also detected this trend for the majority of the markers (TH, vGlut1, Brn3a, calretinin, calbindin) latest after 12 months of age.

Nevertheless, neuron subsets are maintained in the aged retina, and cellular layers are organized properly, even if some reduction of the retina thickness and decreasing density of neurons in the cellular layers are evident in our study. Overall, these findings are in accordance with that reported for albino rats more than 3 months of age [Nadal-Nicolas et al., 2018a] and agree with the conclusions of our previous investigation where the retina in a 36-month-old Octodon degus was described as slightly loosened tissue structure both at light and electron microscopic levels.

In another series of experiments in mice, the responses of RGCs to visual features proved to be generally normal in most cases in aged individuals, only small differences in the physiology of old ganglion cells were seen [Samuel et al., 2011]. Other studies revealed the occur- rence of tissue or even cell type-dependent differences in the autophagic pathways that are primarily affected by aging. In the case of the retina, these differences provide a plausible explanation for the specific pattern of sight loss with age [Rodriguez-Muela et al., 2013]. Together, these data indicate that aging may lead to decreased coverage of the visual field by ganglion cells leading to decreased visual acuity. This agrees with the finding that most ganglion cell dendrites also decreased [Samuel et al., 2011; Nadal-Nicolas et al., 2018a, b]. One would expect the dendritic field size to increase and cell densities to decline. If the cell densities remained the same during aging, one would expect a constant dendritic field size throughout life.

Gao and Hollyfield [1992] reported that cones are less vulnerable to loss than rods during aging. In this present study and in our previous work, we have shown that the cone density also decreased with aging [Kovacs-Valasek et al., 2017], and this age-related loss of photoreceptors was also reported in human [Gao and Hollyfield, 1992; Curcio and Drucker, 1993], rat [Cano et al., 1986; NadalNicolas et al., 2018a, b], and mouse retina [Cunea et al., 2014]. The ONL thinning is less than expected based on cell counting data. This discrepancy can be explained by a gliotic scar forming in the ONL by Müller cell processes that partially compensates the volume loss.

Aging-associated disturbance of calcium homeostasis was described in many previous studies. They reported the age-related alterations of calcium-binding proteins and its different tendencies in CNS [Papazafiri et al., 1995; Kishimoto et al., 1998]. There is a general consensus about the decreasing tendency of calbindin and relatively stable parvalbumin and calretinin expression during normal aging. The previously described decreasing tendency of calbindin expression is supported in our results too, but in contrast to that, our study revealed a midlife peak during aging for parvalbumin and calretinin, but with a declining tendency afterward.

Age-related alterations were observed in the density of rod bipolar cells and the ribbon synapses of rods in $O$. degus [Szabadfi et al., 2015]. We also observed that dendrites of rod bipolar cells sprout well with aging. This alteration is also described in our previous work in aging PACAP KO mouse retina [Kovacs-Valasek et al., 2017]. This reorganization of dendrites is discussed in many other aging studies which describe the same phenomenon in mice and in human retinas [Liets et al., 2006; Eliasieh et al., 2007; Terzibasi et al., 2009; Samuel et al., 2011]. The decreased number of rod bipolar cells in aging retina has also been reported in human tissue earlier [Ag- 
garwal et al., 2007]. Currently it is not known if the sprouts form functional synapses or not, and if this is in connection with the changes in cell number. Accordingly, the age-related sprouting of rod bipolar cell dendrites is in good correlation with previous literary data [Szabadfi et al., 2015; Kovács-Valasek et al., 2017]. At the same time, vGlut1 expression has minimal alteration during the aging process. These findings demonstrate that the expression of synaptic proteins is preserved despite the morphological and neurochemical changes. Synaptic plasticity is maintained during cell degeneration, and this may involve the continuous transporter protein recycling between the plasma membrane and synaptic vesicles in the bipolar cell terminals. This phenomenon can be observed under pathological conditions too [Phillips et al., 2010].

The vGLUT levels showed a moderate decline with aging and other studies described the same tendency in the rodent retina during the aging process [Szabadfi et al., 2015; Kovacs-Valasek et al., 2017]. Photoreceptors are glutamatergic neurons and exclusively express VGLUT1 isoform. If the glutamate reuptake is hindered, the filling of synaptic vesicles maybe insufficient; therefore the release from the terminals will decrease. This might reduce the effectivity the signal transfer to bipolar cells and may require a compensatory vGlut 1 increase [Johnson et al., 2003]. This decrease in vGLUT expression was also discussed in an age-related hearing loss study [Alvarado et al., 2014]. It would be interesting to see if there is any causal correlation between the changes in sirtuins and the abovementioned markers since researchers demonstrated a marked reduction of sirtuin 1 expression in aged retinal neurons [Luo et al., 2017].

Particularly interesting is GFAP from this aspect. Not only the quantity declines after a midlife peak, but also the number of isoforms seem to be less in old animals than in mature adults. A decrease in astrocyte availability has been described where some of the glial cells lose their GFAP content [Mansour et al., 2008]. The lower astrocyte density has been observed in adult rats compared to P18 age and significantly increased from P120 to P480 [Fernandez-Sanchez et al., 2015]. Interestingly, the same phenomenon has not been observed in 36-month-old O. degus. However, we have to note at this point that degu live much longer than rats and this aforementioned age maybe identical with the 18-month-old rats; therefore, the decline of GFAP content could not be seen yet. It is an especially important finding that this midlife peak tendency of GFAP expression was also described in the ventral cochlear nuclei between age groups of 3-, 6-, 12-, and 24-month-old rats [Jalenques et al., 1997]. In the human retina, the GFAP level significantly increases during normal aging [Wu et al., 2003]. The age-related change of astrocyte density increased 3-9 months of age and decreased between 9 and 12 months in Wistar rats [Mansour et al., 2008]. At the same time, GFAP increase is often a sign of metabolic insults. This variation of GFAP expression during aging and metabolic retinal degenerations maybe due to changes in splicing. It is estimated that more than $50 \%$ of all age-associated alterations in alternative splicing are due to changes in the expression of splicing factors [Mazin et al., 2013]. This gives a good theoretical background for differential aging of individual cell types. Maybe glial cell aging is an important factor in the overall retinal tissue aging since glial cells are known to contribute to siphoning $\mathrm{K}^{+}$from the extracellular space and to neutralization of reactive oxygen species that are generated as a consequence of inadequate microcirculation [Reichenbach and Bringmann, 2013].

\section{Possible Mechanisms of Aging in Retinal Tissue}

In most of the studies dealing with aging, both intrinsic and extrinsic factors are determined to contribute to the altered functional capabilities of cellular and molecular mechanism during the aging process. Three different types of physiological changes occur with aging: changes in cellular homeostasis, decrease in organ mass, and decline of functional reserve [Dodds et al., 2006]. Following this scheme, we found in our investigation that these agerelated changes are especially well traceable and can be well documented in the aged retina (Fig. 10). Some aspects are also elucidated in our present study. For example, age-related metabolic changes contribute to the dysregulation of molecular processes and lead to a functional decline through altered cellular communication (blue rectangle in Fig. 10.) and a continuous slow parainflammation (red rectangle in Fig. 10.). Among the gradually decreasing biomarkers, researchers demonstrated a marked reduction of sirtuin 1 expression in aged retinal neurons as well as in retinas injured by acute ischemia reperfusion. In contrast, sirtuin 5 shows significantly higher expression in the retinas of 20 -month-old rats compared to both 2- and 12-month-old animals, but this was not revealed for any other sirtuins during age-related changes [Luo et al., 2017]. This goes parallel with several parameters and markers examined in our study and may be a general phenomenon in the aging process. Furthermore, it is also important to note the facts that age-related changes in retinal gene expression indicative of parainflammation may work synergistically with the parainflammatory processes induced by diabetes to accelerate 


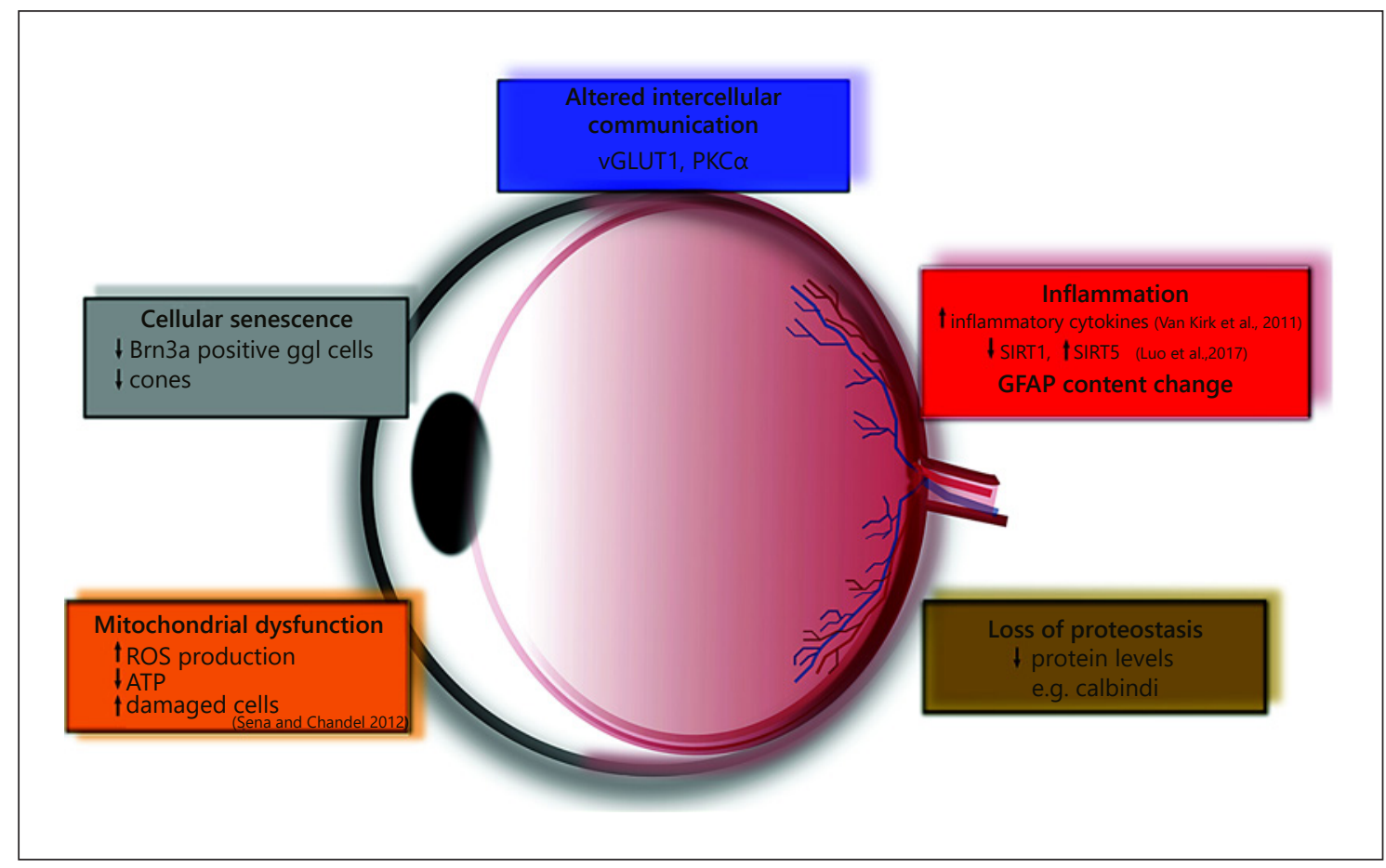

Fig. 10. General scheme of aging in retinal tissue. vGLUT1, vesicular glutamate transporter 1; PKCa, protein kinase C alpha; ROS, reactive oxygen species; ATP, adenosine triphosphate; SIRT1, sirtuin 1; GFAP, glial fibrillary acidic protein.

pathogenesis [Van Kirk et al., 2011], and there are endogenous factors which can counteract both aging and retina-damaging pathologies: NAP [Jehle et al., 2008]; PACAP [Szabadfi et al., 2012]; NGF [Chen et al., 2015]; or GLP-1 [Sampedro et al., 2019]. Monitoring of their appropriate presence and maintenance of their physiological expression during aging maybe the clue for slow aging and longevity of proper retinal function.

The loss of proteostasis is a dominant factor in the aging process; almost all the proteins we examined in our study decrease with old age (brown rectangle in Fig. 10) [Rockstein and Brandt, 1963]. Although not directly examined in our study, there is evidence from the literature that the decline in mitochondrial function and an increase in ROS production damages the cell components (orange rectangle in Fig. 10) and leads to senescence (gray rectangle in Fig. 10) [Sena and Chandel, 2012]. It is also well known that the retinal microvasculature also undergoes remarkable age-related changes. Chan-Ling et al. [2007] described the effect that caused the impairment of the blood-retina barrier in aged rats compared to young adults, and they found significantly increased vascular permeability, decreased tight junction protein expres- sion, and activation of major histocompatibility complex class II-positive and phagocytic microglia [Chan-Ling et al., 2007]. Deteriorated microcirculation maybe a first step to a decline in mitochondrial quality and activity which has been associated with normal aging [Sun et al., 2016]. Besides, the specific inflammatory, neuronal and microvascular genes altered with aging provide potential molecular mechanisms for the well-documented functional impairments and parainflammatory state of the retina with advanced age. Additionally, these results support the hypothesis that diabetes and aging share some common molecular alterations, but it is important to know the patterns of gene expression are not identical [Van Kirk et al., 2011; Gabriel, 2013].These intrinsic and extrinsic hallmarks of aging could be responsible for cellular senescence, cell loss and decline of visual processing capabilities.

\section{Acknowledgement}

The authors thank Alina Bolboaca for the excellent technical assistance. 


\section{Statement of Ethics}

All procedures abided the ethical permission approved by the University of Pécs (BA02/2000-15,024/2011) and followed the ARVO guidelines regarding the protection of animals used for experimental and other scientific purposes.

\section{Conflict of Interest Statement}

The authors have no conflicts of interest to declare.

\section{Funding Sources}

This work was supported by the Hungarian Brain Research Program KTIA_13_NAP-A-I/12-001, NKFIH grant (119289) and EFOP-3.6.2-16-2017-00,008.

\section{Author Contributions}

A.K.-V. wrote the manuscript, performed immunocytochemistry and western blots. E.P. wrote the manuscript, performed western blots, and collected literature.V.D. revised the manuscript, controlled sacrificing and dissection of animals, and supervised blotting. A.M. wrote the manuscript and performed western blots. G.S.Jr carried out confocal microscopy and figure planning. R.G. designed the study, supervised immunocytochemistry, wrote and revised the manuscript.

\section{References}

Aggarwal P, Nag TC, Wadhwa S. Age-related decrease in rod bipolar cell density of the human retina: an immunohistochemical study. J Biosci. 2007 Mar;32(2):293-8.

Alvarado JC, Fuentes-Santamaría V, GabaldónUll MC, Blanco JL, Juiz JM. Wistar rats: a forgotten model of age-related hearing loss. Front Aging Neurosci. 2014;6:29.

Arroba AI, Campos-Caro A, Aguilar-Diosdado M, Valverde ÁM. IGF-1, Inflammation and Retinal Degeneration: A Close Network. Front Aging Neurosci. 2018; 10:203.

Atlasz T, Szabadfi K, Kiss P, Tamas A, Toth G, Reglodi D, et al. Evaluation of the protective effects of PACAP with cell-specific markers in ischemia-induced retinal degeneration. Brain Res Bull. 2010 Mar 16;81(4-5):497-504.

Birch DG, Anderson JL. Standardized full-field electroretinography. Normal values and their variation with age. Arch Ophthalmol. 1992 Nov;110(11):1571-6.

Cano J, Machado A, Reinoso-Suárez F. Morphological changes in the retina of ageing rats. Arch Gerontol Geriatr. 1986 Apr;5(1):41-50.

Chan-Ling T, Hughes S, Baxter L, Rosinova E, McGregor I, Morcos Y, et al. Inflammation and breakdown of the blood-retinal barrier during "physiological aging" in the rat retina: a model for CNS aging. Microcirculation. 2007 Jan;14(1):63-76.

Chaychi S, Polosa A, Lachapelle P. Differences in Retinal Structure and Function between $\mathrm{Ag}$ ing Male and Female Sprague-Dawley Rats are Strongly Influenced by the Estrus Cycle. PLoS One. 2015 Aug 28;10(8):e0136056.

Chen Q, Wang H, Liao S, Gao Y, Liao R, Little PJ, et al. Nerve growth factor protects retinal ganglion cells against injury induced by retinal ischemia-reperfusion in rats. Growth Factors. 2015 Apr;33(2):149-59.

Coleman PD, Flood DG. Neuron numbers and dendritic extent in normal aging and $\mathrm{Al}-$ zheimer's disease. Neurobiol Aging. 1987 Nov-Dec;8(6):521-45.
Cunea A, Powner MB, Jeffery G. Death by color: differential cone loss in the aging mouse retina. Neurobiol Aging. 2014 Nov;35(11):258491.

Curcio CA, Drucker DN. Retinal ganglion cells in Alzheimer's disease and aging. Ann Neurol. 1993 Mar;33(3):248-57.

Deschenes M, Chabot B. The emerging role of alternative splicing in senescence and aging. Aging Cell. 2017 Oct;16(5):918-33.

Djamgoz MB, Hankins MW, Hirano J, Archer SN. Neurobiology of retinal dopamine in relation to degenerative states of the tissue. Vision Res. 1997 Dec;37(24):3509-29.

Dodds C. Physiology of ageing. Anaesthesia \& Intensive Care Medicine. 2006;7(12):456-8.

El-Sayyad HI, Khalifa SA, El-Sayyad FI, Al-Gebaly AS, El-Mansy AA, Mohammed EA. Agingrelated changes of optic nerve of Wistar albino rats. Age (Dordr). 2014 Apr;36(2):519-32.

Eliasieh K, Liets LC, Chalupa LM. Cellular reorganization in the human retina during normal aging. Invest Ophthalmol Vis Sci. 2007 Jun;48(6):2824-30

Endo T, Kobayashi M, Kobayashi S, Onaya T. Immunocytochemical and biochemical localization of parvalbumin in the retina. Cell Tissue Res. 1986;243(1):213-7.

Fernandez-Sanchez L, Lax P, Campello L, Pinilla I, Cuenca N. Astrocytes and Muller Cell Alterations During Retinal Degeneration in a Transgenic Rat Model of Retinitis Pigmentosa. Front Cell Neurosci. 2015;9:484.

Freund PR, Watson J, Gilmour GS, Gaillard F, Sauvé Y. Differential changes in retina function with normal aging in humans. Doc Ophthalmol. 2011 Jun;122(3):177-90.

Fyk-Kolodziej B, Qin P, Dzhagaryan A, Pourcho RG. Differential cellular and subcellular distribution of glutamate transporters in the cat retina. Vis Neurosci. 2004 Jul-Aug;21(4): 551-65.
Gabriel R. Neuropeptides and diabetic retinopathy. Br J Clin Pharmacol. 2013 May;75(5): 1189-201.

Gabriel R, Witkovsky P. Cholinergic, but not the rod pathway-related glycinergic (All), amacrine cells contain calretinin in the rat retina. Neurosci Lett. 1998 May 15;247(2-3):179-82.

Gao H, Hollyfield JG. Aging of the human retina. Differential loss of neurons and retinal pigment epithelial cells. Invest Ophthalmol Vis Sci. 1992 Jan;33(1):1-17.

Garcia-Ayuso D, Di Pierdomenico J, Esquiva G, Nadal-Nicolas FM, Pinilla I, Cuenca N, et al. Inherited Photoreceptor Degeneration Causes the Death of Melanopsin-Positive Retinal Ganglion Cells and Increases Their Coexpression of Brn3a. Invest Ophthalmol Vis Sci. 2015 Jul;56(8):4592-604.

Gkotsi D, Begum R, Salt T, Lascaratos G, Hogg C, Chau KY, et al. Recharging mitochondrial batteries in old eyes. Near infra-red increases ATP. Exp Eye Res. 2014 May;122:50-3.

Graymore CN. Metabolic survival of the isolated retina. Br Med Bull. 1970 May;26(2):130-3.

Jalenques I, Burette A, Albuisson E, Romand R. Age-related changes in GFAP-immunoreactive astrocytes in the rat ventral cochlear nucleus. Hear Res. 1997 May;107(1-2):113-24.

Jehle T, Dimitriu C, Auer S, Knoth R, Vidal-Sanz $\mathrm{M}$, Gozes I, et al. The neuropeptide NAP provides neuroprotection against retinal ganglion cell damage after retinal ischemia and optic nerve crush. Graefes Arch Clin Exp Ophthalmol. 2008 Sep;246(9):1255-63.

Johnson J, Tian N, Caywood MS, Reimer RJ, Edwards RH, Copenhagen DR. Vesicular neurotransmitter transporter expression in developing postnatal rodent retina: GABA and glycine precede glutamate. J Neurosci. 2003 Jan 15;23(2):518-29.

Kam JH, Jeffery G. To unite or divide: mitochondrial dynamics in the murine outer retina that preceded age related photoreceptor loss. Oncotarget. 2015 Sep 29;6(29):26690-701. 
Katz ML, Robison WG Jr. Evidence of cell loss from the rat retina during senescence. Exp Eye Res. 1986 Apr;42(4):293-304.

Kim CB, Tom BW, Spear PD. Effects of aging on the densities, numbers, and sizes of retinal ganglion cells in rhesus monkey. Neurobiol Aging. 1996 May-Jun;17(3):431-8.

Kishimoto J, Tsuchiya T, Cox H, Emson PC, Nakayama Y. Age-related changes of calbindinD28k, calretinin, and parvalbumin mRNAs in the hamster brain. Neurobiol Aging. 1998 Jan-Feb;19(1):77-82.

Kovacs-Valasek A, Szabadfi K, Denes V, Szalontai B, Tamas A, Kiss P, et al. Accelerated retinal aging in PACAP knock-out mice. Neuroscience. 2017 Apr 21;348:1-10.

Kuhrt H, Gryga M, Wolburg H, Joffe B, Grosche J, Reichenbach A, et al. Postnatal mammalian retinal development: quantitative data and general rules. Prog Retin Eye Res. 2012 Nov; 31(6):605-21.

Kumagai AK. Glucose transport in brain and retina: implications in the management and complications of diabetes. Diabetes Metab Res Rev. 1999 Jul-Aug;15(4):261-73.

Liets LC, Eliasieh K, van der List DA, Chalupa LM. Dendrites of rod bipolar cells sprout in normal aging retina. Proc Natl Acad Sci USA. 2006 Aug 8;103(32):12156-60.

$\mathrm{Lu} \mathrm{Y,} \mathrm{Belin} \mathrm{S,} \mathrm{He} \mathrm{Z.} \mathrm{Signaling} \mathrm{regulations} \mathrm{of} \mathrm{neu-}$ ronal regenerative ability. Curr Opin Neurobiol. 2014 Aug;27:135-42.

Lundkvist A, Reichenbach A, Betsholtz C, Carmeliet P, Wolburg H, Pekny M. Under stress, the absence of intermediate filaments from Müller cells in the retina has structural and functional consequences. J Cell Sci. 2004 Jul 15; 117(Pt 16):3481-8.

Luo H, Zhou M, Ji K, Zhuang J, Dang W, Fu S, et al. Expression of Sirtuins in the Retinal Neurons of Mice, Rats, and Humans. Front Aging Neurosci. 2017;9:366.

Majdi M, Ribeiro-da-Silva A, Cuello AC. Variations in excitatory and inhibitory postsynaptic protein content in rat cerebral cortex with respect to aging and cognitive status. Neuroscience. 2009 Mar 17;159(2):896-907.

Mansour H, Chamberlain CG, Weible MW 2nd, Hughes S, Chu Y, Chan-Ling T. Aging-related changes in astrocytes in the rat retina: imbalance between cell proliferation and cell death reduces astrocyte availability. Aging Cell. 2008 Aug;7(4):526-40.

Mazin P, Xiong J, Liu X, Yan Z, Zhang X, Li M, et al. Widespread splicing changes in human brain development and aging. Mol Syst Biol. 2013;9:633.

Mohamed MEI, El-Shaarawy EAA, Youakim MF, Shuaib DMA, Ahmed MM. Aging changes in the retina of male albino rat: a histological, ultrastructural and immunohistochemical study. Folia Morphol (Warsz). 2019;78(2): 237-58.
Nadal-Nicolas FM, Vidal-Sanz M, Agudo-Barriuso $\mathrm{M}$. The aging rat retina: from function to anatomy. Neurobiol Aging. 2018a Jan;61: 146-68.

Nadal-Nicolas FM, Vidal-Sanz M, Agudo-Barriuso $M$. The senescent vision: dysfunction or neuronal loss?. Aging (Albany NY). 2018b Dec 26;11(1):15-7.

Nivison-Smith L, O'Brien BJ, Truong M, Guo CX, Kalloniatis M, Acosta ML. Vinpocetine modulates metabolic activity and function during retinal ischemia. Am J Physiol, Cell Physiol. 2015 May 1;308(9):C737-49.

Panda-Jonas S, Jonas JB, Jakobczyk-Zmija M. Retinal photoreceptor density decreases with age. Ophthalmology. 1995 Dec; 102(12): 1853-9.

Papazafiri P, Podini P, Meldolesi J, Yamaguchi T. Ageing affects cytosolic $\mathrm{Ca} 2+$ binding proteins and synaptic markers in the retina but not in cerebral cortex neurons of the rat. Neurosci Lett. 1995 Feb 15;186(1):65-8.

Parikh RS, Parikh SR, Sekhar GC, Prabakaran S, Babu JG, Thomas R. Normal age-related decay of retinal nerve fiber layer thickness. Ophthalmology. 2007 May;114(5):921-6.

Pasteels B, Rogers J, Blachier F, Pochet R. Calbindin and calretinin localization in retina from different species. Vis Neurosci. 1990 Jul;5(1): $1-16$.

Phillips MJ, Otteson DC, Sherry DM. Progression of neuronal and synaptic remodeling in the rd10 mouse model of retinitis pigmentosa. J Comp Neurol. 2010 Jun 1;518(11):2071-89.

Reichenbach A, Bringmann A. New functions of Müller cells. Glia. 2013 May;61(5):651-78.

Rockstein M, Brandt KF. Enzyme changes in flight muscle correlated with aging and flight ability in the male housefly. Science. 1963 Mar 15;139(3559):1049-51.

Rodriguez-Muela N, Koga H, Garcia-Ledo L, de la Villa P, de la Rosa EJ, Cuervo AM, et al. Balance between autophagic pathways preserves retinal homeostasis. Aging Cell. 2013 Jun; 12(3):478-88

Roufail E, Rees S. Ageing has a differential effect on nitric oxide synthase-containing and catecholaminergic amacrine cells in the human and rat retina. J Comp Neurol. 1997 Dec 15; 389(2):329-47.

Sampedro J, Bogdanov P, Ramos H, Solà-Adell C, Turch M, Valeri M, et al. New Insights into the Mechanisms of Action of Topical Administration of GLP-1 in an Experimental Model of Diabetic Retinopathy. J Clin Med. 2019 Mar 11;8(3).

Samuel MA, Zhang Y, Meister M, Sanes JR. Agerelated alterations in neurons of the mouse retina. J Neurosci. 2011 Nov 2;31(44):1603344.
Sanna PP, Keyser KT, Battenberg E, Bloom FE. Parvalbumin immunoreactivity in the rat retina. Neurosci Lett. 1990 Oct 2;118(1):136-9.

Semo M, Peirson S, Lupi D, Lucas RJ, Jeffery G, Foster RG. Melanopsin retinal ganglion cells and the maintenance of circadian and pupillary responses to light in aged rodless/coneless (rd/rd cl) mice. Eur J Neurosci. 2003 May; 17(9):1793-801.

Sena LA, Chandel NS. Physiological roles of mitochondrial reactive oxygen species. Mol Cell. 2012 Oct 26;48(2):158-67.

Sivapathasuntharam C, Sivaprasad S, Hogg C, Jeffery G. Aging retinal function is improved by near infrared light $(670 \mathrm{~nm})$ that is associated with corrected mitochondrial decline. Neurobiol Aging. 2017 Apr;52:66-70.

Sun N, Youle RJ, Finkel T. The Mitochondrial Basis of Aging. Mol Cell. 2016 Mar 3;61(5):65466.

Szabadfi K, Atlasz T, Kiss P, Reglodi D, Szabo A, Kovacs K, et al. Protective effects of the neuropeptide PACAP in diabetic retinopathy. Cell Tissue Res. 2012 Apr;348(1):37-46.

Szabadfi K, Estrada C, Fernandez-Villalba E, Tarragon E, Setalo G Jr., Izura V, et al. Retinal aging in the diurnal Chilean rodent (Octodon degus): histological, ultrastructural and neurochemical alterations of the vertical information processing pathway. Front Cell Neurosci. 2015;9:126

Tacutu R, Budovsky A, Yanai H, Fraifeld VE. Molecular links between cellular senescence, longevity and age-related diseases - a systems biology perspective. Aging (Albany NY). 2011 Dec;3(12):1178-91.

Tedeschi A, Omura T, Costigan M. CNS repair and axon regeneration: Using genetic variation to determine mechanisms. Exp Neurol. 2017 Jan;287(Pt 3):409-22.

Terzibasi E, Calamusa M, Novelli E, Domenici L, Strettoi E, Cellerino A. Age-dependent remodelling of retinal circuitry. Neurobiol Aging. 2009 May;30(5):819-28.

Trick GL, Nesher R, Cooper DG, Shields SM. The human pattern ERG: alteration of response properties with aging. Optom Vis Sci. 1992 Feb;69(2):122-8.

Van Kirk CA, VanGuilder HD, Young M, Farley JA, Sonntag WE, Freeman WM. Age-related alterations in retinal neurovascular and inflammatory transcripts. Mol Vis. 2011;17: 1261-74

Weisse I. Changes in the aging rat retina. Ophthalmic Res. 1995;27(Suppl 1):154-63.

Wu KH, Madigan MC, Billson FA, Penfold PL. Differential expression of GFAP in early v late AMD: a quantitative analysis. Br J Ophthalmol. 2003 Sep;87(9):1159-66.

Xu H, Chen M, Forrester JV. Para-inflammation in the aging retina. Prog Retin Eye Res. 2009 Sep;28(5):348-68.

Zahn JM, Kim SK. Systems biology of aging in four species. Curr Opin Biotechnol. 2007 Aug;18(4):355-9. 